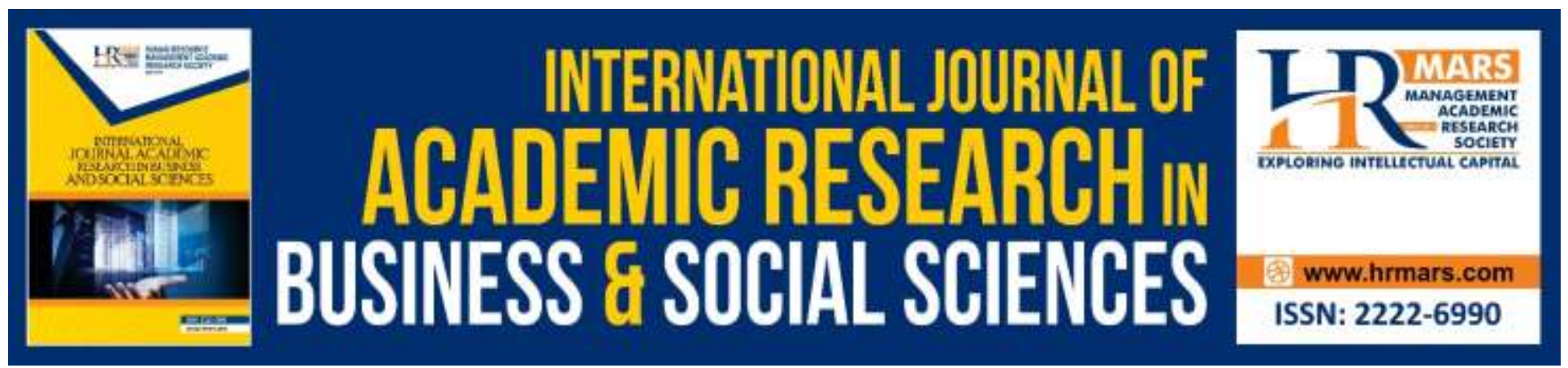

\title{
Measuring Intention to buy Air freshener product based on Brand Name, Packaging, Product Quality, Price, and Advertising in Indonesia
}

Mia Wahyu Nuraini, Wella Wahyu Qur'anna, Diyang Nurjanah, Jehan Sekarkinasih, David Yusuf Firnanda, Hujjatullah Fazlurrahman

To Link this Article: http://dx.doi.org/10.6007/IJARBSS/v9-i7/6139 DOI: $10.6007 /$ IJARBSS/v9-i7/6139

Received: 18 May 2019, Revised: 07 June 2019, Accepted: 29 June 2019

Published Online: 21 July 2019

In-Text Citation: (Nuraini et al., 2019)

To Cite this Article: Nuraini, M. W., Qur'anna, W. W., Nurjanah, D., Sekarkinasih, J., Firnanda, D. Y., \& Fazlurrahman, H. (2019). Measuring Intention to buy Air freshener product based on Brand Name, Packaging, Product Quality, Price, and Advertising in Indonesia. International Journal of Academic Research in Business and Social Sciences, 9(7), 470-483.

Copyright: (C) 2019 The Author(s)

Published by Human Resource Management Academic Research Society (www.hrmars.com)

This article is published under the Creative Commons Attribution (CC BY 4.0) license. Anyone may reproduce, distribute, translate and create derivative works of this article (for both commercial and non-commercial purposes), subject to full attribution to the original publication and authors. The full terms of this license may be seen at: http://creativecommons.org/licences/by/4.0/legalcode

Vol. 9, No. 7, 2019, Pg. $470-483$

Full Terms \& Conditions of access and use can be found at http://hrmars.com/index.php/pages/detail/publication-ethics 


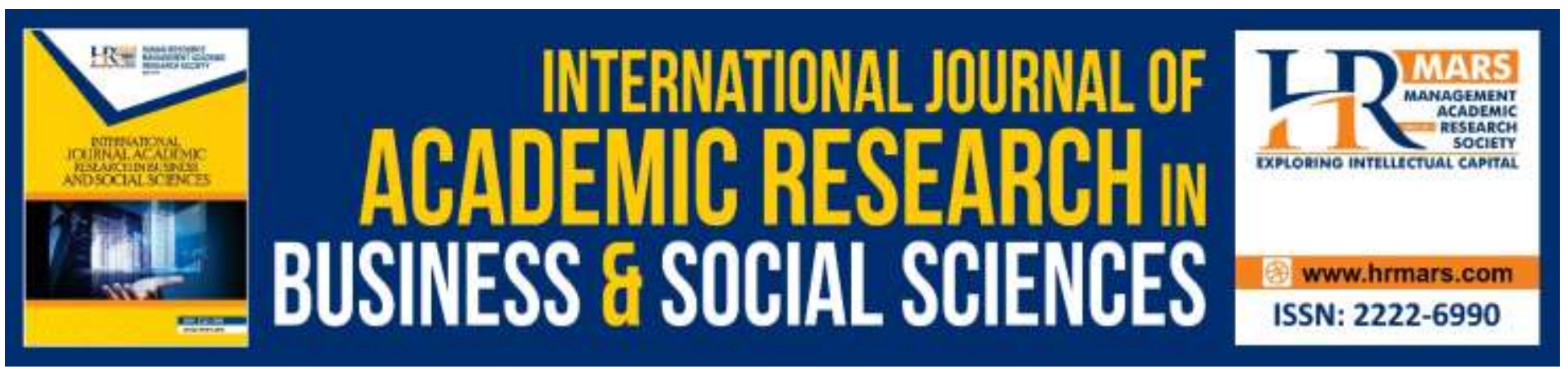

\title{
Measuring Intention to buy Air freshener product based on Brand Name, Packaging, Product Quality, Price, and Advertising in Indonesia
}

\author{
Mia Wahyu Nuraini, Wella Wahyu Qur'anna, Diyang Nurjanah, \\ Jehan Sekarkinasih, David Yusuf Firnanda, Hujjatullah \\ Fazlurrahman, S. E.
}

Department of Management, Faculty of Economics, Universitas Negeri Surabaya, Surabaya

Unesa Kampus Ketintang Surabaya Indonesia

Email: miawahyuwn@gmail.com, elitec26@gmail.com, diyang.dn@gmail.com, jehansk99@gmail.com, davidyusuff12@gmail.com, hujjatullahfazlurrahman@unesa.ac.id

\begin{abstract}
Purpose: This research aims to measure buying interest from air freshener. This product is new and wants to measure market willingness and the extent to which this product is in demand by consumers Method: This research uses an online questionnaire to get the respondents. There are 5 variables that influence buying intention. The sampling technique using non-probability sampling with a sample size of 85. Data analysis techniques using multiple regression

Result: Brand name, packaging, product quality and advertising variables have no effect on buying interest while prices have a significant effect on buying interest

Limitation: This research is conducted in the second largest city (Surabaya) in Indonesia.

Originality / Value - This paper suggests contribution to the board of directors' air freshener product Keyword: Brand Name, Packaging, Product Quality, Price, Advertising, Purchase Intention and Air Freshener.
\end{abstract}

\section{Introduction}

Every product that is produced and offered to consumers is of course a product that has its own charm, both from the manufacturer's side and from the consumer side. The appeal of these products is product excellence such as product uniqueness, product quality, economic benefits, persuasiveness in advertising, and so on. Product attractiveness is a booster factor of consumer buying interest in the products offered, as well as air freshener products that have an appeal that is able to attract consumers' buying interest. Interest in buying itself according to Kotler and Keller (2016) is a consumer behavior where consumers have the desire to buy or choose a product, based on experience in choosing, using and consuming or even wanting a product. The interest in buying 
consumers is based on several factors such as, Brand Name, Packaging, Product Quality, Price, Advertising. The five factors are the attractiveness of a product, so there is a correlation with consumer buying interest.

Brand Name according to Richardson, Dick, and Jain (1994) used extrinsic cues to infer and / or maintain perceptions of quality and represent information about a product, in an air freshener product that has a unique Brand Name because air freshener stands for Dry Room Anti-Air Freshener Mosquitoes are a piece of identity and product information.

Packaging according to Olson and Jacoby (1972) are attributes related to products but not part of the physical product itself, Packaging Room Fragrances that carry the Shabby Chic theme and use burlap cloth as the packaging is unique and becomes a product identity and is true not a physical part from the Bunker product itself because the core of the Bunker is dried flowers.

Quality products according to Kotler and Armstrong (2012) are the product's ability to perform its functions, it includes the product's overall durability, reliability, precision, operation and repair, and other valued attributes. Product Quality offered from room fragrances is the use of natural ingredients and minimizes the use of chemicals that are safer to use in terms of health that are classified as product quality.

Price according to Kotler and Keller (2014) price is one element of the marketing mix that generates income, this element produces costs. Price is the easiest element in marketing programs to adjust, product features, channels and even communication requires a lot of time. The price offered on room fragrances is Rp. 20,000 which are classified as economical with all the advantages and quality of products that are suitable even though it still has shortcomings but all can be tolerated and the room fragrances themselves always try to suppress all deficiencies to maximize customer satisfaction and attract other consumers to buy.

Advertising according to Jefkins (1997) is the most persuasive sales message that is directed to (potential) the most potential consumers of certain goods or services at the most economical cost. Room fragrances in advertising are quite persuasive and effective, as evidenced by the existence of a number of sales platforms that can attract consumers' buying interest, which have now entered the era of the Industrial Revolution, where everything must be fast, practical, and efficient. In addition, by using influencer services that are now very influential quickly in the minds of consumers, as well as participating in bazaar or SME programs to expand the product introduction network to consumers.

The five things above are factors that have a relationship and influence consumer buying interest in the product. This has an impact on buying interest in fragrances. This research measures the extent to which consumers buy interest in air freshener products that will be launched into the market.

\section{Literature Review \\ Brand Name}

Brand names are generally used extrinsic cues to infer and / or maintain perceived quality and can represent a collection of information about a product (Richardson, Dick, and Jain, 1994). Smith, Brynjolfson (2001), emphasizes that despite ongoing consideration of the importance of branding as a marketing strategy for strong positioning and differentiation, consumers use brand names as a 
symbol of dependence on service quality for non-contract aspects of products. However, marketers are aware of this, they tend to cut short process naming (Kronrod \& Lowrey, 2016), which can cause brand names to not reach their highest standards in serving their goals.

Gontijo, Rayman, Zhang and Zaidel (2002) study revealed that brand names are easily processed and more accurate than if not words but less accurate and slower to process when common nouns are used. A well-known brand name that is associated with a positive brand image creates competitive advantage in terms of increasing consumer interest, attention, and positive evaluation of a product, and encouraging repeat purchases (Shen, 2001).

Consumers tend to allocate more attention to known brands and make more efforts to process information about a product with a well-known brand name (Shen, 2001). When consumers lack knowledge about the attributes of a product and are uncertain about the product, brand names play a role important in reducing perceived risk and assessing product quality (Dean, 1999).

The brand name becomes a powerful tool for multinational corporations in standardization and training positives, profitable market share in international frontiers (Adamu \& Bambale, 2016). English and Japanese brand names were used to control conclusions and variations in prior knowledge of each individual product (Moriuchi \& Jackson, 2017).

\section{Packaging}

One of the most popular is packaging and most attractive products (Farooq, Habib, \& Aslam, 2014). Product packaging has a strong influence on consumer purchase intentions especially at the point of sale (Khan, Waheed, \& Ahmad, 2018). Packaging is an attribute associated with the product but not part of the physical product itself (Olson and Jacoby, 1972). While Arens (1996) explains that packaging is a product container that includes the physical appearance of the container, including design, color, labeling, shape, and materials used. Design, quality and color of packaging has a strong influence on consumer purchasing behavior. Packaging is the main selling proposition that helps consumers to differentiate products (Silayoi, \& Speece, 2007). Packaging can also be interpreted as an object that serves to protect certain products that are in it and can provide certain images to persuade users (Mudra, 2010).

Packaging material is a useful tool for convenience and competitive advantage, Packaging materials are also important to protect the product, if the material is used enough, customers are attractive to the products. (Hussain, Ibrahim, \& Noreen, 2015). Roduct packaging plays an integral role for conveying the brand message to its target customers (Nancarrow, 1998). The visual aspect of packaging has a role in establishing direct relationships with customers and their effects on customer mind (Deng, 2009).

\section{Product Quality}

According to Kotler and Armstrong (2012: 283) product quality is "the product's ability to perform its functions, it includes the product's overall durability, reliability, precision, ease of operation and repair, and other value-valued attributes." Garvin (1998) have proposed the following eight dimensions of quality: (1) Performances : a product's primary operating characteristic. (2) Features: the additional features or bells and whistles of the product, (3) Conformance: the product's design and operating characteristics, which are the probability that a product will operate (a) Serviceability: 
the speed, competence, and courtesy of a specified period of time under stated conditions of use, (5) Serviceability: the speed, competence, and courtesy of repair, (7) Aesthetics: how a product appeals to our five senses, (8) Customer perceived quality: customer's perception of a quality product based on the reputation on the fi (Wang \& Li-Yan, 2016) ...

The rank of the consumers in United States placed for product quality are as follows (1) reliability, (2) durability, (3) easy maintenance, (4) ease of use, (5) a trusted brand name and (6) low price (McDaniel, Lamb and Hair, 2011). Product quality is a key factor in assessing purchase intention. It is a continuous process of improvement that results in continuous changes in product performance and consequently the satisfaction of customers' needs (Tobergte \& Curtis, 2013).

\section{Price}

The price is defined as the money exchange customers in terms of service or product, or the value they receive (Kotler and Armstrong, 2012). Price is what is sacrificed or given to obtain a product or a service (Amir Elnaga \& Amen Imran, 2013). Price is important factors of purchase of private brands, focusing on products with low prices regardless of product characteristics (Karampour \& Ahmadinejad, 2016). The product price has been considered a key predictor of consumers' purchase decision-making (Lien, Wen, Huang, \& Wu, 2015).

According to Kotler and Keller (2014). price is one element of the marketing mix that generates income, this element generates costs. Price is the easiest element in marketing programs to adjust, product features, channels and even communication requires a lot of time. According to Kotler and Keller (2014), there are five main objectives in setting prices, namely: (1) Ability to survive: companies pursue the ability to survive as their main goal if they experience excess capacity, fierce competition, or changing consumer desires. As long as prices cover other variable costs and fixed costs the company stays in the business; (2) Maximum current profit: Many companies try to set prices that will maximize a company's profits estimating demand and costs associated with relative prices and choosing prices that produce current profits, cash flows or maximum return on investment.

The Maximum Third Market Share The company believes that the higher the sales volume, the lower unit costs and the higher long-term profits. The company sets the lowest price assuming the market is price sensitive. Fourth Market Skimming Pricing, companies reveal new technologies that set high prices to maximize flushing in the market where prices are initially set high and slowly drop over time. Fifth, product quality leadership Many brands strive to be "affordable luxury" products or services that are character-determined by high levels of perceived quality, taste and status at a high enough price so as not to be beyond the reach of consumers.

\section{Advertising}

Advertising is a subset of promotion mix that is asp (product, price, place and promotion) in the marketing mix. Advertising as one of the strategies of promotion, is an important tool in creating awareness in the minds of potential customers in order to make a decision to buy the product (Tobergte \& Curtis, 2013). Advertising according to Jefkins (1997) is the most persuasive sales messages that are directed to (potential) the most potential consumers of certain goods or services at the most economical cost. 
In order for advertisements to successfully stimulate buyers' actions, according to Kotler and Keller (2014) at least must meet the AIDA criteria (attention, interest, desire action) Attention contains attraction, interest contains attention and interest, Desire raises the desire to try or have, Action leads to action buy

Based on the AIDA concept, advertising promotion must require sufficient knowledge about behavior patterns, needs, and market segments. The concept is expected that consumers can make continuous purchases. All the efforts of advertising in the persuasive language style try to make consumers consume, regardless of their social status. Advertising according to Jefkins (1997) is the most persuasive sales messages that are directed to (potential) the most potential consumers of certain goods or services at the most economical cost.

\section{Purchase Intention}

Menurut (Ha \& Janda, 2014) Purchase intention is defined as a consumer's willingness to purchase products or services from a particular web site. The purchasing decision-making process involves identifying a need that must be satisfied; looking for relevant information regarding the product's benefits and product quality in order to make an informed decision; evaluating all the products available that could possibly satisfy one's need; purchasing and consuming the chosen product; and then evaluating whether the product did indeed meet one's desires and needs (Du Plessis \& Rousseau, 2007:263). Purchase intention is the likelihood that a customer will buy a particular product/service (Dodds, Monroe, \& Grewal, 1991)

the motivational influences to purchase a given brand name such as advertising, sales promotion, public relations and so forth has had positive effect on consumer purchase intentions(Adamu \& Bambale, 2016). A product being of various sizes influences consumer purchase intention more significantly than an item which is of only one size (ford, et al, 2012). Morgan and Rego (2006), discussed in their study "repurchase intentions are the most widely used indicator of customer loyalty in firms' customer feedback systems"

Table 1. List of literature review

\begin{tabular}{|l|l|l|l|l|}
\hline No & Author(s) & Product & Relationship Variable & Result \\
\hline 1. & $\begin{array}{l}\text { (Sundalangi, Mandey, \& } \\
\text { Jopie Jorie, 2014) }\end{array}$ & Pizza hut & $\begin{array}{l}\text { Product quality } \\
\text { purchase intention }\end{array}$ & Significant \\
\hline 2. & (Burhanudin, 2017) & Traveloka & $\begin{array}{l}\text { Advertising } \\
\text { purchase intention }\end{array}$ & $\begin{array}{l}\text { Advertising sot signicant } \\
\text { purchase intention }\end{array}$ \\
\hline 3. & (Tobergte \& Curtis, 2013) & Bono brand & $\begin{array}{l}\text { Product quality } \\
\text { purchase intention }\end{array}$ & Significant \\
\hline & & $\begin{array}{l}\text { Price } \rightarrow \text { purchase } \\
\text { intention }\end{array}$ & Not significant \\
\hline & & $\begin{array}{l}\text { Packaging } \rightarrow \text { purchase } \\
\text { intention }\end{array}$ & Not significant \\
\hline
\end{tabular}


INTERNATIONAL JOURNAL OF ACADEMIC RESEARCH IN BUSINESS AND SOCIAL SCIENCES Vol. 9, No. 7, July, 2019, E-ISSN: 2222-6990 @ 2019 HRMARS

\begin{tabular}{|l|l|l|l|l|}
\hline No & Author(s) & Product & Relationship Variable & Result \\
\hline 4. & $\begin{array}{l}\text { (Calvo-Porral, Martínez- } \\
\text { Fernández, Juanatey-Boga, } \\
\text { \& Lévy-Mangín, 2015) }\end{array}$ & store & $\begin{array}{l}\text { Brand Name } \\
\text { purchase intention }\end{array}$ & Significant \\
\hline 5. & (Kurnia, 2016) & store & $\begin{array}{l}\text { Product quality } \\
\text { purchase intention }\end{array}$ & Significant \\
\hline 6 & (Park \& Lennon, 2009) & $\begin{array}{l}\text { Online } \\
\text { shopping }\end{array}$ & $\begin{array}{l}\text { Brand name } \\
\text { purchase intention }\end{array}$ & Significant \\
\hline 7. & $\begin{array}{l}\text { (Karampour } \\
\text { Ahmadinejad, 2016) }\end{array}$ & $\begin{array}{l}\text { Brand name } \\
\text { surchase intention }\end{array}$ & Significant \\
\hline 8. & (Adamu \& Bambale, 2016) & store & $\begin{array}{l}\text { Brand name } \\
\text { purchase intention }\end{array}$ & Significant \\
\hline 9. & (Farooq et al., 2014) & Lifestyle & $\begin{array}{l}\text { packaging } \\
\text { purchase intention }\end{array}$ & $\begin{array}{l}\text { Positive } \\
\text { Significant }\end{array}$ \\
\hline 10. & (Khan et al., 2018) & Food & $\begin{array}{l}\text { packaging } \\
\text { purchase intention }\end{array}$ & Significant \\
\hline
\end{tabular}

The results of research conducted by Porral et al., (2015), Park \& Lennon (2009), Karampour \& Ahmadinejad (2016), Adamu \& Bambale (2016) show that Brand Name has a significant effect on Purchase Intention.

Hypothesis 1: Does the Brand affect purchase intention

The results of research conducted by Khan, Waheed \& Ahmad (2018), Farooq, Habib \& Aslam (2014) show that Packaging has a significant positive effect on Purchase Intention. The Tobergte \& Curtis (2013) study showed different results that Packaging did not significantly influence Purchase Intention.

Hypothesis 2: Does packaging affect purchase intention

The results of research conducted by Kurnia (2016), Tobergte \& Curtis (2013), Sundalangi, Mandey \& Jopie Jorie (2014) show that Product Quality has a significant effect on Purchase Intention

Hypothesis 3: Is the quality of the product thought to affect purchase intention

The results of research conducted by Tobergte \& Curtis (2013) show that Price does not significantly influence Purchase Intention.

H4: Does the price affect Purchase Intention

The results of the research conducted by Burhanudin (2017) show that Advertising has a significant effect on Purchase Intention. Sundalangi, Mandey \& Jopie Jorie (2014) research shows different results that Advertising does not significantly influence Purchase Intention

H5: Does the advertisement affect buying interest. 


\section{Conceptual Framework}

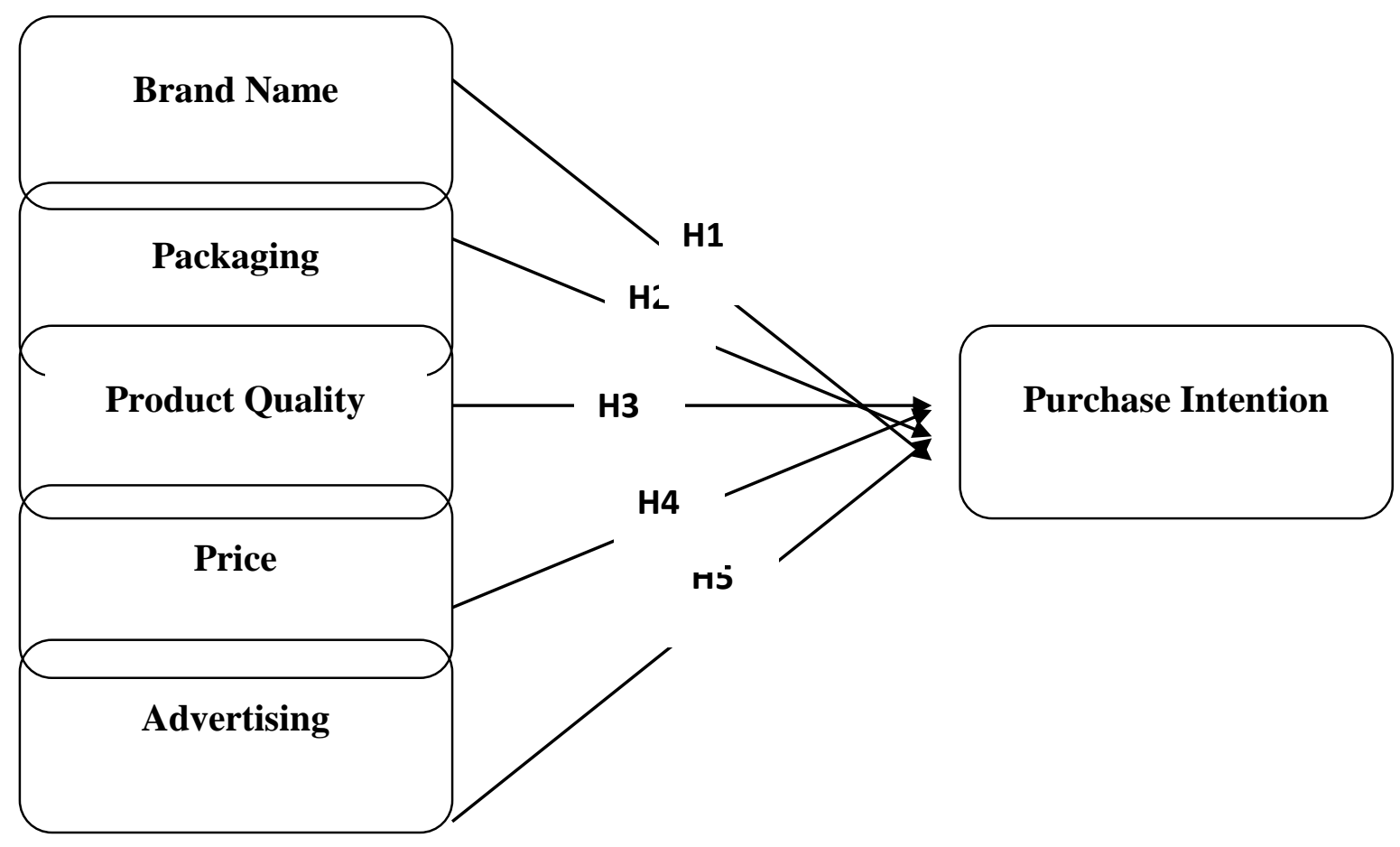

\section{Methodology}

This research is a causal research, it is to analyze the influence of Brand Name, Packaging, Product Quality, Price, Advertising on purchase intention The population used in this research is the candidate customer on air freshener product. The sample size in this study was 85 sample and using nonprobability sampling with quota sampling method to determine the study sample. Hypothesis testing technique used is multiple linear regression test.

Determination of sample size based on Sekaran (2014) which explains the sample size from 30 - 500 samples. Testing the research instrument using validity and reliability tests. the validity value must be above 0.4 and the reliability value must be above 0.8 (Sekaran, 2014) 
INTERNATIONAL JOURNAL OF ACADEMIC RESEARCH IN BUSINESS AND SOCIAL SCIENCES

Vol. 9, No. 7, July, 2019, E-ISSN: 2222-6990 @ 2019 HRMARS

\section{Result}

Tabel 2 validity testing

\begin{tabular}{|c|c|c|}
\hline Variabel & Value & Kolom \\
\hline M1 & 0.510 & 5 \\
\hline $\mathrm{M} 2$ & 0.461 & 5 \\
\hline M3 & 0.839 & 5 \\
\hline M4 & 0.830 & 5 \\
\hline K1 & 0.695 & 2 \\
\hline $\mathrm{K} 2$ & 0.674 & 2 \\
\hline $\mathrm{K} 3$ & 0.392 & 2 \\
\hline $\mathrm{K} 4$ & 0.505 & 2 \\
\hline $\mathrm{K} 5$ & 0.745 & 2 \\
\hline Ku1 & 0.163 & 4 \\
\hline Ku2 & 0.651 & 4 \\
\hline Ku3 & 0.799 & 4 \\
\hline $\mathrm{H} 1$ & 0.041 & 1 \\
\hline $\mathrm{H} 2$ & -0.119 & 1 \\
\hline $\mathrm{H3}$ & 0.163 & 1 \\
\hline $\mathrm{H} 4$ & 0.901 & 1 \\
\hline $\mathrm{H} 5$ & 0.877 & 1 \\
\hline$I 1$ & 0.588 & 6 \\
\hline 12 & 0.614 & 6 \\
\hline 13 & 0.385 & 6 \\
\hline 14 & 0.167 & 6 \\
\hline 15 & 0.019 & 6 \\
\hline MB1 & 0.196 & 3 \\
\hline MB2 & 0.202 & 3 \\
\hline MB3 & 0.156 & 3 \\
\hline
\end{tabular}

The table above shows that the Brand Name variable has met the standard validity test with a coefficient value above 0.40 which means that the variable is valid. Packaging Variables There are 4 items that are said to be valid with a coefficient value above 0.40 but there is 1 item that has not been valid with a coefficient of 0.392 . Product Quality variable shows there are 2 items that are said to be valid with a coefficient value above 0.40 and there is 1 item that has not been valid with a coefficient value of 0.163 .

Price variable there are 2 items that are said to be valid with coefficient values above 0.40 and 3 items are not valid with a coefficient value of less than 0.40 . Advertising variable shows that there are 2 items that are said to be valid with coefficient values above 0.40 and 3 items are not valid with a coefficient value of less than 0.40. Variable Purchase Intention indicates that 3 items have a coefficient value of less than 0.40 . This shows that the Purchase Intention variable is invalid because it has not met the standard validity test with a coefficient value of less than 0.40 .

Tabel 3 Reliability testing 
INTERNATIONAL JOURNAL OF ACADEMIC RESEARCH IN BUSINESS AND SOCIAL SCIENCES Vol. 9, No. 7, July, 2019, E-ISSN: 2222-6990 @ 2019 HRMARS

\begin{tabular}{|c|c|c|}
\hline Variabel & $\begin{array}{l}\text { Cronbach's Alpha } \\
\text { Based on } \\
\text { Standardized items }\end{array}$ & $\begin{array}{l}\text { Cronbach's } \\
\text { Alpha }\end{array}$ \\
\hline M1 & 0.944 & 0.937 \\
\hline $\mathrm{M} 2$ & 0.944 & 0.936 \\
\hline M3 & 0.944 & 0.939 \\
\hline M4 & 0.944 & 0.936 \\
\hline K1 & 0.944 & 0.935 \\
\hline K2 & 0.944 & 0.937 \\
\hline K3 & 0.944 & 0.937 \\
\hline K4 & 0.944 & 0.936 \\
\hline K5 & 0.944 & 0.935 \\
\hline Ku1 & 0.944 & 0.935 \\
\hline Ku2 & 0.944 & 0.938 \\
\hline Ku3 & 0.944 & 0.939 \\
\hline $\mathrm{H} 1$ & 0.944 & 0.939 \\
\hline $\mathrm{H} 2$ & 0.944 & 0.939 \\
\hline $\mathrm{H3}$ & 0.944 & 0.938 \\
\hline $\mathrm{H} 4$ & 0.944 & 0.939 \\
\hline $\mathrm{H} 5$ & 0.944 & 0.937 \\
\hline I1 & 0.944 & 0.938 \\
\hline 12 & 0.944 & 0.936 \\
\hline 13 & 0.944 & 0.936 \\
\hline 14 & 0.944 & 0.936 \\
\hline 15 & 0.944 & 0.937 \\
\hline MB1 & 0.944 & 0.936 \\
\hline MB2 & 0.944 & 0.937 \\
\hline MB3 & 0.944 & 0.937 \\
\hline
\end{tabular}

Table 4 Reliability Statistics

Cronbach's Alpha Based on Standardized Items $\mathrm{N}$ of Items

\begin{tabular}{l|l}
.944 & 25 \\
\hline
\end{tabular}

both tables show that each variable can be said to be reliable with a coefficient value above 0.80 . This value indicates that this research variable has a strong reliable value. 
INTERNATIONAL JOURNAL OF ACADEMIC RESEARCH IN BUSINESS AND SOCIAL SCIENCES

Vol. 9, No. 7, July, 2019, E-ISSN: 2222-6990 @ 2019 HRMARS

Table 5 Model Summary

\begin{tabular}{|l|l|l|l|l|}
\hline Model & & & & Std. Error of the \\
& R & R Square & Adjusted R Square & Estimate \\
\hline d 1 & $.747^{a}$ & .559 & .531 & .54343 \\
m & & & & \\
e & & & & \\
s & & & & \\
o & & & & \\
$n$ & & & & \\
0 & & & & \\
\hline
\end{tabular}

The results of the R-square analysis show that the influence of Brand Name, Packaging, Product Quality, Price, and Advertising on purchase intention has an R-square value of 0.559, which means the magnitude of the influence model in this study is $55.9 \%$ and $44.1 \%$ is explained by other variables not examined.

Table 6 ANOVA ${ }^{\mathrm{b}}$

\begin{tabular}{|ll|l|l|l|l|l|}
\hline \multicolumn{2}{|l|}{ Model } & $\begin{array}{l}\text { Sum } \\
\text { Squares }\end{array}$ & $\mathrm{df}$ & $\begin{array}{l}\text { Mean } \\
\text { Square }\end{array}$ & $\mathrm{F}$ & Sig. \\
\hline 1 & Regression & 29.525 & 5 & 5.905 & 19.995 & $.000^{\text {a }}$ \\
& Residual & 23.330 & 79 & .295 & & \\
& Total & 52.855 & 84 & & & \\
\hline
\end{tabular}

the results of the $\mathrm{F}$ Test analysis, it shows that when the Brand Name, Packaging, Product Quality, Price, Advertising variables are tested together, they significantly influence Purchase Intention and have a coefficient of 19,995.

Table 7 Coefficients $^{a}$

\begin{tabular}{|ll|l|l|l|l|l|}
\hline \multicolumn{2}{|l|}{ Model } & \multicolumn{2}{l|}{$\begin{array}{l}\text { Unstandardized } \\
\text { Coefficients }\end{array}$} & \multicolumn{2}{l|}{$\begin{array}{l}\text { Standardized } \\
\text { Coefficients }\end{array}$} & \\
\cline { 3 - 5 } & & $\mathrm{B}$ & Std. Error & Beta & $\mathrm{t}$ & Sig. \\
\hline 1 & (Constant) & -.205 & .555 & & -.369 & .713 \\
& $\mathrm{M}$ & .050 & .101 & .055 & .501 & .617 \\
$\mathrm{~K}$ & .056 & .192 & .045 & .295 & .769 \\
$\mathrm{Ku}$ & .018 & .201 & .011 & .087 & .931 \\
& $\mathrm{H}$ & .760 & .123 & .626 & 6.176 & .000 \\
& $\mathrm{I}$ & .099 & .130 & .086 & .755 & .452 \\
\hline
\end{tabular}


The results of the T test showed that when the Brand Name, Packaging, Product Quality, Price, Advertising variables were tested separately against Purchase Intention having the following coefficient values: Brand Name was 0.501, Packaging was 0.295, Product Quality was 0.087, Price was 6.176, and Advertising amounting to 0.755. other the results of the t-test analysis showed that Brand Name, Packaging, Product Quality and advertising did not significantly affect purchase intention while only the price variable had a significant effect on purchase intention.

\section{Discussion and Conclusion}

Hypothesis 1 suggests that brand names are influential on purchase intention. The above statistical results prove that brand name does not influence purchase intention. These results indicate that the brand name of the fragrances does not affect the purchase intention. However, this statistical result is different from the research conducted by Park \& Lennon, (2009), Karampour \& Ahmadinejad, (2016), Adamu \& Bambale, (2016), that brand name influences brand name.

This difference in results is caused by different types of products and air freshener including low involvement product (Kotler and Keller, 2014). These air freshener products do not require longer thinking and consideration in making purchasing decisions.

Hypothesis 2 is assumed that packaging has an effect on purchase intention. Regression results that measure the effect of packaging on purchase intention are not significant. The results of this study are the same as the results of the research conducted (Tobergte \& Curtis, 2013). However, the results of research conducted by (Adamu \& Bambale, 2016) and Khan, Waheed, \& Ahmad, 2018) show that packaging has an effect on purchase intention.

Packaging from this air freshener product is simple and attractive. However, the regression results indicate that packaging has no effect on purchase intention. Research conducted by (Adamu \& Bambale, 2016) and Khan, Waheed, \& Ahmad, 2018) explains that packaging has an effect on purchase intention because the object of research is lifestyle and food products.

Hypothesis 3 is thought to have an effect on Product Quality on Purchase Intention. The results of statistical calculations show that product quality does not affect purchase intention. This is in contrast to the results of research conducted by Sundalangi, Mandey, \& Jopie Jorie, 2014), (Tobergte \& Curtis, 2013), (Kurnia, 2016). These results indicate that the respondents did not know the product quality of the air freshener product.

Hypothesis 4 is thought to have an effect on purchase intention. The regression results indicate that price has an effect on purchase intention. This is because the price of the product under study is cheap. However, the results are different from the research conducted by (Tobergte \& Curtis, 2013), price does not affect the purchase intention.

The hypothesis 5 is thought to be influential advertising on purchase intention. The results of statistical calculations explain that advertising does not affect purchase intention. The results are the same as the research conducted (Tobergte \& Curtis, 2013). However, the results of different research conducted by (Farooq, Habib, \& Aslam, 2014), (Khan, Waheed, \& Ahmad, 2018) which show that advertising influences purchase intention 
INTERNATIONAL JOURNAL OF ACADEMIC RESEARCH IN BUSINESS AND SOCIAL SCIENCES

Vol. 9, No. 7, July, 2019, E-ISSN: 2222-6990 @ 2019 HRMARS

\section{References}

Adamu, U. G., \& Bambale, A. J. (2016). The Effect of Brand Name on Consumer Purchase Intention in Kano Metropolis : A Conceptual Model. International Journal of Management and Commerce Innovations, 4(1), 58-63. Retrieved from file://C:/Users/dell/Downloads/The Effect of Brand Name-3084 (3).pdf

Arens, F. W. (1996), Contemporary Advertising, Irwin, United States of America: Mcgraw-hill Higher Education.

Burhanudin, R. (2017). PENGARUH IKLAN TRAVELOKA DI TELEVISI TERHADAP MINAT BELI KONSUMEN (Studi di Indonesia). E-Proceeding of Management, 4(2), 1453-1459.

Calvo-Porral, C., Martínez-Fernández, V. A., Juanatey-Boga, O., \& Lévy-Mangín, J. P. (2015). Measuring the influence of customer-based store brand equity in the purchase intention. Cuadernos de Gestion, 15(1), 93-118. https://doi.org/10.5295/cdg.130408cc

Dean, D. H. (1999), "Brand endorsement, popularity, and event sponsorship as advertising cues affecting consumer pre-purchase attitudes", Journal of Advertising, Vol. 28 No. 3, pp. 1-12.

Farooq, S., Habib, S., \& Aslam, S. (2014). Influence of Product Packaging on Purchase Decisions. European Journal of Social and Human Sciences , 2014, Vol.(3 ), № 3, III(2012), 144-150.

Jefkins, F. (1997). Periklanan Edisi III. Penerbit Erlangga.

Garvin, D.A. (1998), Managing Quality: The Strategic and Competitive Edge, The Free Press, New York)

Gontijo, P. F. D., Rayman, J., Zhang, S., \& Zaidel, E. (2002). How brand names are special: Brands, words and hemispheres. Brain and Language, 82, 327-343

Ha, H. Y., \& Janda, S. (2014). The effect of customized information on online purchase intentions. Internet Research, 24(4), 496-519. https://doi.org/10.1108/IntR-06-2013-0107

Hussain, S., Ibrahim, M., \& Noreen, A. (2015). Impact of Product Packaging on Consumer Perception and Purchase Intention. Journal of Marketing and Consumer Research, 10(2011), 1-10.

Karampour, A., \& Ahmadinejad, B. (2016). Purchase Intention for a Private Label Brand : Direct Impact of Factors including Price Sensitivity, Understanding Brand, Image of Private Brands and Mental Image of Store : Case Study : Etka Chain Stores. Kuwait Chapter of Arabian Journal of Business and Management Review, 3(7), 417-426. https://doi.org/10.12816/0018300

Khan, M. M., Waheed, S., \& Ahmad, N. (2018). Product Packaging and Consumer Purchase Intentions. Market Forces College of Management Sciences, volume 13(December), 97-114.

Kotler, P. and Armstrong, G. (2012). Principles of marketing. 14th ed. Boston: Pearson Prentice Hall. Kotler, P. and Keller, K. (2014) Marketing Management. 15th Edition, Prentice Hall, Saddle River

Kronrod, Ann \& Lowrey, Tina M., 2016. "Tastlé-Nestlé, Toogle-Google: The effects of similarity to familiar brand names in brand name innovation," Journal of Business Research, Elsevier, vol. 69(3), pages 1182-1189

Kurnia, M. R. (2016). Pengaruh Merek, Kualitas Produk Dan Promosi Terhadap Keputusan Pembelian Peralatan Olahraga Tenis Meja Oke Sport Di Kecamatan Wonosari. Jurnal Bisnis Dan Ekonomi (JBE), 24(1), 33.

Lien, C. H., Wen, M. J., Huang, L. C., \& Wu, K. L. (2015). Online hotel booking: The effects of brand image, price, trust and value on purchase intentions. Asia Pacific Management Review, 20(4), 210-218. https://doi.org/10.1016/j.apmrv.2015.03.005

Moriuchi, E., \& Jackson, P. R. (2017). Role of brand names and product types on bicultural consumers' 
INTERNATIONAL JOURNAL OF ACADEMIC RESEARCH IN BUSINESS AND SOCIAL SCIENCES

Vol. 9, No. 7, July, 2019, E-ISSN: 2222-6990 @ 2019 HRMARS

purchase intentions. Journal of Consumer Marketing, 34(1), 53-65.

https://doi.org/10.1108/JCM-10-2014-1190

Olson, J. C. \& Jacoby, J. (1972). Cue Utilization in the quality Perception Process, in Proceedings, ed. M. Venkatesan, Association for Consumer Research, pp. 167-179.

Park, M., \& Lennon, S. J. (2009). Brand name and promotion in online shopping contexts. Journal of Fashion Marketing and Management: An International Journal, 13(2), 149-160. https://doi.org/10.1108/13612020910957680

Richardson, P. S., Dick, A., \& Jain, A. K. (1994).Extrinsic and intrinsic cue effects on perception of store brand quality. Journal of Marketing, 58, $28 \pm 36$

Shen, F. (2001), "Effects of violence and brand familiarity on responses to television commercial", International Journal of Advertising, Vol. 20, pp. 381-97.

Silayoi, P., \& Speece, M. (2007). The importance of packaging attributes: A conjoint analysis approach. European Journal of Marketing, 41(11-12), 1495-1517. http://dx.doi.org/10.1108/03090560710821279

Smith, Michael D. \& Brynjolfsson, Erik. (2001). "Consumer Decision-making at an Internet Shopbot: Brand Still Matters," NBER Chapters,in: E-commerce, pages 541-558 National Bureau of Economic Research, Inc.

Sundalangi, M., Mandey, S. L., \& Jopie Jorie, R. (2014). Kualitas Produk, Daya Tarik Iklan, Dan Potongan Harga Terhadap Minat Beli Konsumen Pada Pizza Hut Manado. Jurnal EMBA, 2(1), 313-324.

Tobergte, D. R., \& Curtis, S. (2013). A Study of Factors Affecting on Customers Purchase Intention Case Study: the Agencies of Bono Brand Tile in Tehran. Journal of Chemical Information and Modeling, 53(9), 1689-1699. https://doi.org/10.1017/СB09781107415324.004

Wang, Y. H., \& Li-Yan, C. (2016). An Empirical Study of the Effect of Perceived Price on Purchase Intention Evidence from Low-Cost Carriers. International Journal of Business and Social Science, 7(4), 41170. Retrieved from www.ijbssnet.com 